\title{
Biogenic Amine Production in Olomouc Curd Cheese (Olomoucké tvarůžky) at Various Storage Conditions
}

\author{
Eva Standarová, Lenka Vorlová, Pavlína Kordiovská, Bohumíra Janštová, \\ Michaela Dračková, Ivana Borkovcová \\ Department of Milk Hygiene and Technology, Faculty of Veterinary Hygiene and Ecology, \\ University of Veterinary and Pharmaceutical Sciences Brno, Czech Republic
}

Received January 26, 2009

Accepted June 30, 2009

\begin{abstract}
The aim of this study was to evaluate the effects of temperature and storage time on the formation of biogenic amines (BAs) in the traditional Czech curd cheese (Olomoucké tvarůžky). Samples were stored for 7 weeks at $5{ }^{\circ} \mathrm{C}$ and $20^{\circ} \mathrm{C}$. BAs were studied as dansyl derivatives by the RP-HPLC method with fluorescence detection, histamine was determined using a photodiode array detector. Physical and chemical properties were analyzed as specified by the Czech National Standard, as were the sensory characteristics (colour, odour, texture and flavour). The major amines found were cadaverine (124-2 $\left.413 \mathrm{mg} \cdot \mathrm{kg}^{-1}\right)$ and tyramine $\left(117-1058 \mathrm{mg} \cdot \mathrm{kg}^{-1}\right)$, followed by putrescine $\left(75-767 \mathrm{mg} \cdot \mathrm{kg}^{-1}\right)$ and histamine $\left(74-411 \mathrm{mg} \cdot \mathrm{kg}^{-1}\right)$. Low concentrations of tryptamine, spermine and spermidine were present. Total concentrations of BAs significantly increased with storage time $(P<0.01)$, depending significantly on temperature $(P<0.01)$. Total BAs in cheese stored at $20{ }^{\circ} \mathrm{C}$ compared to $5{ }^{\circ} \mathrm{C}$ were more than three times higher, reaching $4600 \mathrm{mg} \cdot \mathrm{kg}^{-1}$ at the end of storage. The toxicologically critical value of $900 \mathrm{mg} \cdot \mathrm{kg}^{-1}$ for the sum of histamine + tyramine + putrescine + cadaverine was reached 17 days later in the cheese stored at $5{ }^{\circ} \mathrm{C}$ compared to $20{ }^{\circ} \mathrm{C}$. When stored at $5{ }^{\circ} \mathrm{C}$, the samples retained adequate sensory characteristics for the entire safe storage time. The effects of storage conditions on BAs formation are relevant to reducing the risk associated with consumption of cheese high in BAs.
\end{abstract}

Olomoucké tvarůžk, smear-ripened cheese, cadaverine, tyramine, storage conditions, temperature, sensory analysis, HPLC

Biogenic amines (BAs histamine, tyramine, tryptamine, phenylethylamine and cadaverine) are low molecular organic bases produced mostly by decarboxylation of free amino acids with catalysis of bacterial decarboxylases (Silla-Santos 1996). Polyamines (putrescine, spermidine and spermine, introduced as components of the BAs family) are considered as a distinct group because they can be also produced by another metabolic pathway and for their different physiological action (putrescine is considered both BA and polyamine) (Kalač and Krausová 2005).

Histamine and tyramine are the most studied BAs due to their toxicological effect. Histamine can cause dilatation of blood vessels and arteries, resulting in headaches, hypotension, gastrointestinal diseases and oedemas (Stratton et al. 1991). Tyramine is a vasoconstrictor, provoking hypertension and migraine, and can implicate brain haemorrhage and heart disturbance (Křížek and Kalač 1998). Histamine and tyramine are degraded in the organism by oxidative deamination catalyzed by monoamine and/or diamine oxidase (MAO; DAO) (Bardócz et al. 1993). The presence of MAO and DAO inhibitors or the presence of other BAs such as diamines (putrescine and cadaverine) can potentiate their toxicity. Attention has been devoted to the diamines putrescine and cadaverine, and polyamines spermidine and spermine, because they can be precursors of carcinogenic nitrosamines and may enhance the growth of chemically induced aberrant crypt foci in the intestine (Paulsen et al. 1997b). As polyamines are required for cell proliferation, it is very important to control the polyamine content in the diet of cancer patients (Kalač and Krausová 2005). 
There are some cases when detoxification mechanisms in humans fail: high individual susceptibility (alergic individuals, patiens consuming drugs with MAO inhibitors), too high intake of BAs in the diet, presence of other potentiating compounds. For these reasons, it is difficult to establish toxic doses of BAs (Halász et al. 1994; Komprda 2005). However, the value suggested by Spanier et al. (1991) that the aggregate of histamine + tyramine + putrescine + cadaverine should not exceed the level $900 \mathrm{mg} \cdot \mathrm{kg}^{-1}$ is conventionally used for cheese.

Cheese is the second (after fish) most frequently presented food item associated with BA poisoning (Stratton et al. 1991). Presence of microorganisms with decarboxylase activity is one of the main factors affecting the BA content in cheese; it can be lactic acid bacteria (LAB) used as starter culture (Fernández-García et al. 2000) and the action of non-starter lactic acid bacteria or some other spontaneous microflora (Roig-Sagués et al. 2002). Strains of a wide range of genera, such as enterobacteria, Pseudomonas and LAB, are able to produce BAs. The capability of BA formation seems to be strain-dependent rather than related to species specificity. It is thus difficult to find precise correlations between BA contents and the microorganism counts (Valsamaki et al. 2000). Several factors influence the BA content in cheese: cheese production conditions (Kř́žzek and Kalač 1998), time of ripening and storage (Kř́ížek and Kalač 1998; Valsamaki et al. 2000), milk pasteurization (Rak 2005), and starter culture (Roig-Sagués et al. 2002).

The aim of this study was to determine the production of hygienically important BAs in the Olomouc curd cheese (Olomoucké tvarǔžky), in which commercial samples with dangerous BA levels were detected in the past. Olomoucké tvarůžky is a sour-milk spiced hand-made cheese, which is very easily characteristized by its strong scent and yellowish colour (Council Regulation (EC) No. 510/2006). A common feature of these varieties is the typical maturation from the surface to the center of the cheese owing to smear microflora (Forman 1996). The cheese is dispatched from the dairy to retail at approximately onethird of the maturing process. This fact necessitates the study of the impact of storage (e.g. a period that involves shipping the cheese from the dairy, commercial distribution and reselling to final consumption) at various temperatures on BA formation.

\section{Materials and Methods}

Cakes of Olomouc curd cheese designated as big ones by the producer were acquired as commercial products directly from the producer at the time of dispatch. The samples were uniformly divided into two groups and stored over a period of 7 weeks at various temperatures (cool box temperature of $5^{\circ} \mathrm{C}$ and room temperature of $20^{\circ} \mathrm{C}$ ). The temperature of $5^{\circ} \mathrm{C}$ represents the storage temperature recommended by the producer, and the temperature of $20{ }^{\circ} \mathrm{C}$ represents the commonly used increased storage temperature, corresponding to room temperature.

For the analysis, 12 samples were collected from each group at weekly intervals (i.e. week 0 to week 7). A total of 180 samples were analysed.

The individual physical and chemical properties were determined according to the Czech technical standards ( $\breve{C S N}$ ) (pH and titratable acidity according to the ČSN 570107, fat content according to the ČSN EN ISO 1735 , dry matter content according to the ČSN ISO 5534 and $\mathrm{NaCl}$ content according to the ČSN ISO 5943). Water activity $a_{w}$ was determined using the apparatus AW Sprint TH-500 (Novasina, Switzerland).

The BAs (histamine, tyramine, cadaverine, tryptamine, 2-phenylethylamine) and polyamines (putrescine, spermidine, and spermine) were determined by high performance liquid chromatography (HPLC) method with precolumn derivatization with dansylchloride (DCl) (Paulsen et al. 1997a), modified for the establishment of BAs in cheeses.

Five g of homogenous sample were extracted with $45 \mathrm{ml}$ of $10 \%$ trichloracetic acid (TCA) by disintegration and magnetic stirrer for $5 \mathrm{~min}$. The suspension was filtered, the filtrate made up to $50 \mathrm{ml}$ with $10 \%$ TCA and filtered through a nylone membrane filter $0.45 \mu \mathrm{m}$ (and stored at $-18{ }^{\circ} \mathrm{C}$ until the final analysis).

Derivatization was carried out by the following method: $0.8 \mathrm{ml}$ of the sample extract (or the standard) and $0.1 \mathrm{ml}$ of an internal standard 1,7-diaminoheptane (1,7-DH) were pippetted to a $50 \mathrm{ml}$ flask; then, $1 \mathrm{ml}$ of saturated solution of $\mathrm{NaHCO}_{3}$ and $1 \mathrm{ml}$ derivatization agent $(\mathrm{DCl})$ were added. The $\mathrm{pH}$ of this solution was modified to 10.5. After closing the flask and intensive shaking of the mixture, derivatization continued in a water bath at $70{ }^{\circ} \mathrm{C}$ over 10 min with no access to light. The liquid phase was later evaporated on an evaporation dish at $45^{\circ} \mathrm{C}$, and the remaining solids were dissolved in $1 \mathrm{ml}$ of acetonitrile $(\mathrm{ACN})$. The solution was then filtered over a $0.45 \mu \mathrm{m}$ membrane filter and kept in a vial for injecting onto the column. 
The BA standards were derivatized similarly to the procedure followed for derivatization of samples (acquired as BA hydrochlorides from the Sigma-Aldrich Company, USA). The same company also supplied the internal standard 1,7-diaminoheptane). Standard solutions were prepared by dissolving 10-50 mg of BA (calculated on the pure substance) in $0.1 \mathrm{M} \mathrm{HCl}$ with the final volume of $25 \mathrm{ml}$. Solutions were freshly made every 14 days and stored at $4{ }^{\circ} \mathrm{C}$ in a dark place.

Analyses were carried out on a liquid chromatograph Alliance 2695 (Waters, USA) with photodiode array detectors (for histamine determination) and a fluorescence detector. Separation after DCl derivatization was carried out by gradient elution (composition of mobile phases and elution profile by Paulsen et al. 1997a) at a column Polaris C 18 (Varian, USA), $150 \mathrm{~mm} \times 4.6 \mathrm{~mm}$, particle size of $3 \mu \mathrm{m}$ with precolumn Meta Guard Polaris C 18 (Varian, USA), $30 \mathrm{~mm} \times 4.6 \mathrm{~mm}, 3 \mu \mathrm{m}$ tempered to $35^{\circ} \mathrm{C}$, mobile-phase flow rate of $1 \mathrm{ml} \cdot \mathrm{min}^{-1}$. The eluted dansyl derivates were detected by two detectors: by measuring fluorescence at $330 \mathrm{~nm}$ and $500 \mathrm{~nm}$ as excitation and emission lengths and photometrically at $254 \mathrm{~nm}$, respectively. The evaluation was carried out using the Empower software (Waters, USA). The separated BAs were identified by comparing their retention times with those of the standards. For quantification, the method of internal standard specified by Komprda et al. (2007) was used in the procedure. The method was validated using the EffiValidation 3 software (Effichem, Czech Rep.). For the individual BAs, levels of determination of the method ranged from $0.03 \mathrm{mg} \cdot \mathrm{kg}^{-1}$ (putrescine and cadaverine) to $0.1 \mathrm{mg} \cdot \mathrm{kg}^{-1}$ (histamine). Repeatability of the analytical process ranged from $0.7 \%$ (cadaverine) to $5.5 \%$ (spermine). Recovery of the method ranged from $89.0 \%$ for spermidine to $110.8 \%$ for putrescine, with the exception of $78.5 \%$ for tryptamine.

Sensory analysis (colour, odour, texture and flavour) was done by 5 panelists, who gave a score for each sample according to their perceptions of each colour, odour and flavour attributes using a nonstructured hedonic scale in which samples were given scores of 1 (the worst) to 10 (the best). Texture scores were evaluated (from worst to best) by the tasters during slicing. The total sensory score was calculated by the method of Kondyli et al. (2008). Importance was given predominantly to the attributes of flavor, odour and texture over the colour of cheese. Thus the scores obtained for these attributes were multiplied by 5 (flavour and odour mean) and 4 (texture), respectively. The total sensory scores were obtained by adding the scores for all sensory attributes. An excellent cheese received a total score of 100 .

Samples were analysed in duplicates. Correlation coefficients and other statistics were calculated using GraphPad Software (Instat3, Prism5) (GraphPad Software, Inc., La Jolla, USA). Before the actual testing, BoxCox transformation was applied on the data, because the conditions for normality of the basic distribution were not met. Further, the data were processed using Bartlett's test for homogeneity of variances, Student's $t$-test, analysis of variance and Tukey's test of significance of differences.

\section{Results and Discussion}

\section{Biogenic amines}

The total BA content ranged from $403 \mathrm{mg} \cdot \mathrm{kg}^{-1}$ to $516 \mathrm{mg} \cdot \mathrm{kg}^{-1}$ in the studied samples of the Olomouc curd cheese before delivery to the market. Furthermore, in the cheese samples taken directly from the retail chains during the shelf-time, much higher BAs levels were observed. Dičáková and Dudriková (2007) found in retail chain samples a BA content ranging from $445 \mathrm{mg} \cdot \mathrm{kg}^{-1}$ to $2447 \mathrm{mg} \cdot \mathrm{kg}^{-1}$. Rak (2005) reported for the same type of cheese BA concentrations as high as $7860 \mathrm{mg} \cdot \mathrm{kg}^{-1}$. High BA concentrations in commercial samples can be attributed to two factors: (1) Cakes of Olomouc curd cheese are shipped for retail sale before maturation is complete, (2) before analysis sampling, the samples are stored for different periods. Sampling can be done just before the end of the expiration period. It is the period of ripening and storage that is considered one of the key factors influencing the results of BA production (Giraffa et al. 1995).

The influence of storage temperature $\left(5^{\circ} \mathrm{C}\right.$ and $\left.20^{\circ} \mathrm{C}\right)$ on the BA content in Olomouc curd cheese was studied (Tables 1 and 2). The predominant BAs determined at both storage temperatures were tyramine, cadaverine, histamine, and putrescine, whereas the contents of tryptamine, spermine, and spermidine were low; 2-phenylethylamine was not detected.

\section{Histamine}

At both storage temperatures, the histamine content increased at a significant rate $(P<0.01)$ throughout the storage period with the exception of the final week. At $20{ }^{\circ} \mathrm{C}$, histamine contents throughout the storage period were approximately twofold compared to the contents at $5{ }^{\circ} \mathrm{C}$, and they reached up to $411 \mathrm{mg} \cdot \mathrm{kg}^{-1}$ in week 6 . Given that the toxic threshold dose for histamine is $100 \mathrm{mg} \cdot \mathrm{kg}^{-1}$ (Halász et al. 1994; Silla-Santos 1996), it is 
Table 1. Biogenic amine content during storage of Olomouc curd cheese at $5^{\circ} \mathrm{C}$ a

\begin{tabular}{|c|c|c|c|c|c|c|c|}
\hline \multirow{2}{*}{$\begin{array}{l}\text { Time of } \\
\text { storage } \\
(\text { week })\end{array}$} & \multicolumn{7}{|c|}{ Biogenic amines $\left(\mathrm{mg} \cdot \mathrm{kg}^{-1}\right)$} \\
\cline { 2 - 9 } & TRM $^{\mathrm{b}}$ & PUT $^{\mathrm{b}}$ & CAD $^{\mathrm{b}}$ & HIM $^{\mathrm{b}}$ & TYM $^{\mathrm{b}}$ & SPD $^{\mathrm{b}}$ & SPM $^{\mathrm{b}}$ \\
\hline 0 & $5.8 \pm 0.8$ & $75.8 \pm 13.7$ & $124 \pm 12.2$ & $74.4 \pm 5.7$ & $117 \pm 10.1$ & $1.2 \pm 0.1$ & $4.8 \pm 0.6$ \\
\hline 1 & $9.3 \pm 4.3$ & $66.3 \pm 15.0$ & $153 \pm 24.1$ & $83.8 \pm 7.9$ & $105 \pm 8.6$ & $1.8 \pm 0.4$ & $3.7 \pm 0.5$ \\
\hline 2 & $7.1 \pm 1.2$ & $66.8 \pm 17.0$ & $144 \pm 13.2$ & $93.5 \pm 9.8$ & $120 \pm 12.4$ & $1.0 \pm 0.3$ & $2.7 \pm 0.6$ \\
\hline 3 & $8.2 \pm 2.3$ & $212 \pm 39.2$ & $300 \pm 52.4$ & $166 \pm 26.9$ & $224 \pm 50.2$ & $3.1 \pm 0.9$ & $5.1 \pm 0.5$ \\
\hline 4 & $11.4 \pm 3.2$ & $254 \pm 33.0$ & $452 \pm 107$ & $216 \pm 49.9$ & $217 \pm 27.2$ & $7.3 \pm 1.5$ & $12.1 \pm 2.3$ \\
\hline 5 & $4.0 \pm 1.5$ & $321 \pm 59.0$ & $553 \pm 137$ & $244 \pm 50.9$ & $239 \pm 57.3$ & $8.6 \pm 1.3$ & $13.4 \pm 0.9$ \\
\hline 6 & $8.9 \pm 2.2$ & $243 \pm 18.3$ & $617 \pm 20.8$ & $248 \pm 16.3$ & $243 \pm 17.0$ & $7.2 \pm 0.9$ & $9.6 \pm 1.0$ \\
\hline 7 & $19.0 \pm 8.9$ & $174 \pm 52.1$ & $446 \pm 92.6$ & $188 \pm 75.6$ & $190 \pm 90.3$ & $3.6 \pm 1.2$ & $4.8 \pm 0.8$ \\
\hline
\end{tabular}

${ }^{a}$ Contents are expressed in the form of mean \pm standard deviation of the mean $\left(\mathrm{mg} \cdot \mathrm{kg}^{-1}\right)$ for $\mathrm{n}=5$

${ }^{\mathrm{b}} \mathrm{TRM}=$ tryptamine, $\mathrm{PUT}=$ putrescine, $\mathrm{CAD}=$ cadaverine, $\mathrm{HIM}=$ histamine, $\mathrm{TYM}=$ tyramine, $\mathrm{SPD}=$ spermidine, $\mathrm{SPM}=$ spermine

Table 2. Biogenic amine content during storage of Olomouc curd cheese at $20{ }^{\circ} \mathrm{C}$ a

\begin{tabular}{|c|c|c|c|c|c|c|c|}
\hline \multirow{2}{*}{$\begin{array}{l}\text { Time of } \\
\text { storage } \\
(\text { week })\end{array}$} & \multicolumn{7}{|c|}{ Biogenic amines $\left(\mathrm{mg} \cdot \mathrm{kg}^{-1}\right)$} \\
\cline { 2 - 8 } & TRM $^{\mathrm{b}}$ & PUT $^{\mathrm{b}}$ & CAD $^{\mathrm{b}}$ & HIM $^{\mathrm{b}}$ & TYM $^{\mathrm{b}}$ & SPD $^{\mathrm{b}}$ & SPM $^{\mathrm{b}}$ \\
\hline 0 & $5.8 \pm 0.8$ & $75.8 \pm 13.7$ & $124 \pm 12.2$ & $74.4 \pm 5.7$ & $117 \pm 10.1$ & $1.2 \pm 0.1$ & $4.8 \pm 0.6$ \\
\hline 1 & $12.3 \pm 3.2$ & $148 \pm 9.6$ & $369 \pm 26.3$ & $177 \pm 18.9$ & $267 \pm 17.5$ & $3.7 \pm 0.9$ & $8.3 \pm 1.0$ \\
\hline 2 & $53.3 \pm 12.7$ & $242 \pm 56.5$ & $662 \pm 93.3$ & $285 \pm 64.6$ & $485 \pm 82.5$ & $4.2 \pm 0.9$ & $8.9 \pm 1.8$ \\
\hline 3 & $42.6 \pm 14.5$ & $427 \pm 118$ & $471 \pm 111$ & $321 \pm 33.2$ & $524 \pm 102$ & $5.5 \pm 1.9$ & $16.2 \pm 1.2$ \\
\hline 4 & $59.0 \pm 15.5$ & $614 \pm 79.5$ & $776 \pm 184$ & $409 \pm 74.7$ & $668 \pm 119$ & $7.2 \pm 1.7$ & $18.6 \pm 1.1$ \\
\hline 5 & $24.8 \pm 17.1$ & $767 \pm 107$ & $1951 \pm 315$ & $332 \pm 67.2$ & $895 \pm 192$ & $16.1 \pm 1.5$ & $48.4 \pm 4.5$ \\
\hline 6 & $75.9 \pm 22.9$ & $681 \pm 58.1$ & $2413 \pm 216$ & $411 \pm 41.9$ & $1058 \pm 136$ & $14.4 \pm 1.2$ & $32.8 \pm 1.6$ \\
\hline 7 & $74.2 \pm 25.4$ & $344 \pm 69.5$ & $1051 \pm 312$ & $263 \pm 55.9$ & $798 \pm 131$ & $7.9 \pm 1.7$ & $21.3 \pm 4.2$ \\
\hline
\end{tabular}

${ }^{a}$ Contents are expressed in the form of mean \pm standard deviation of the mean $\left(\mathrm{mg} \cdot \mathrm{kg}^{-1}\right)$ for $\mathrm{n}=5$

${ }^{\mathrm{b}} \mathrm{TRM}=$ tryptamine, $\mathrm{PUT}=$ putrescine, $\mathrm{CAD}=$ cadaverine, $\mathrm{HIM}=$ histamine, $\mathrm{TYM}=$ tyramine, $\mathrm{SPD}=$ spermidine, $\mathrm{SPM}=$ spermine

a serious finding that the histamine content exceeded this value in week 3 of storage at $5{ }^{\circ} \mathrm{C}$ and in week 1 of storage at $20^{\circ} \mathrm{C}$. This result is consistent with Joosten's finding (Joosten $1988)$ that high temperature $\left(>14^{\circ} \mathrm{C}\right)$ promotes histamine production.

\section{Tyramine}

The tyramine content significantly increased during the entire period of storage with the exception of the final week 7. A significant increase in the concentrations of tyramine $(P<0.01)$ at both the storage temperatures was observed, and a difference was found during their production. When stored at $5{ }^{\circ} \mathrm{C}$, the BA content increased within 3 weeks and then did not change until the end of storage. When stored at $20^{\circ} \mathrm{C}$, the tyramine content increased linearly and reached the levels of $>1 \mathrm{~g} \cdot \mathrm{kg}^{-1}$ of cheese in week 6 . This level exceeded the toxic threshold dose for tyramine $100-800 \mathrm{mg} \cdot \mathrm{kg}^{-1}$ according to ten Brink et al. (1990). In cheese, tyramine is considered the main biogenic amine (Stratton et al. 1991), and was found in cheeses at high concentrations (Komprda et al. 2007).

\section{Other biogenic amines}

When cakes of Olomouc curd cheese were stored, very high putrescine contents were found. A significant increase in the putrescine content $(P<0.01)$ was observed at both temperatures (Tables 1 and 2); the maximum was always reached in week 5 of storage, when the putrescine content at $20{ }^{\circ} \mathrm{C}$ reached up to $766 \mathrm{mg} \cdot \mathrm{kg}^{-1}$. The putrescine concentration 
at $5{ }^{\circ} \mathrm{C}$ was approximately half the amount. As in the cases of histamine and tyramine, low temperature retarded the BA production by about 3 weeks. Previous researches found similarly high putrescine levels in unripened cheeses $\left(611 \mathrm{mg} \cdot \mathrm{kg}^{-1}\right)($ Novella-Rodríguez et al. 2000). A drop in putrescine production at the end of the storage period in the present experiment is comparable to the data of Joosten (1988), who found that putrescine production in cheese is reduced after 30 days. Valsamaki et al. (2000) found that putrescine concentration in Feta cheese decreased after 60 days of storage. Toxicologically, putrescine is known to have a lower pharmacological activity than aromatic amines, but it is the potentiator of their activity (Joosten 1988).

Cadaverine is the biogenic amine found at the highest concentrations in cheeses in the present experiment (Table 1 and 2). There was a significant increase in its concentration $(P<0.01)$ at both the storage temperatures: at $20^{\circ} \mathrm{C}$, an increase was already detected in week 1 , whereas at $5{ }^{\circ} \mathrm{C}$, the increased levels were not detected until week 3 of storage. Contents of about $2 \mathrm{~g} \cdot \mathrm{kg}^{-1}$, detected at weeks 5 and 6 of storage (2 $413 \mathrm{mg} \cdot \mathrm{kg}^{-1}$, week 6) at $20{ }^{\circ} \mathrm{C}$ were the markers of food spoilage. Such high levels are exceptional. In bryndza (Slovak sheep cheese), Greif et al. (1997) found cadaverine at $1208 \mathrm{mg} \cdot \mathrm{kg}^{-1}$, and similarly high contents were also reported by Halász et al. (1994). Similar to putrescine, cadaverine also acts as a potentiator of the activity of aromatic amines (Joosten 1988).

Tryptamine contents were found to be low (Table 1 and 2). Low levels of this BA in cheese varieties were also found by other researchers (Petridis and Steinhart 1995). In the present experiment the influence of temperature and storage were demonstrated when cheeses were stored at $20{ }^{\circ} \mathrm{C}$ only, particularly at the end of the storage period. Low tryptamine content is usually attributed to the absence of tryptophan in casein, which acts as the precursor of tryptamine. However, the toxic threshold for tryptamine is not known (Joosten 1988).

\section{Polyamines}

The polyamines spermidine and spermine were present at low levels. Only a mild increase in the spermine concentration was observed when stored at $20^{\circ} \mathrm{C}$. Simon-Sarkadi and Hodosi (1995) established the presence of spermidine and spermine in cheese at a wide range of concentrations from undetectable to the level of $192 \mathrm{mg} \cdot \mathrm{kg}^{-1}$.

Total biogenic amines

The total BA content increased during storage depending on the temperature (Fig. 1). At $5^{\circ} \mathrm{C}$, the increase was not detected until week 2 of storage and total BA content

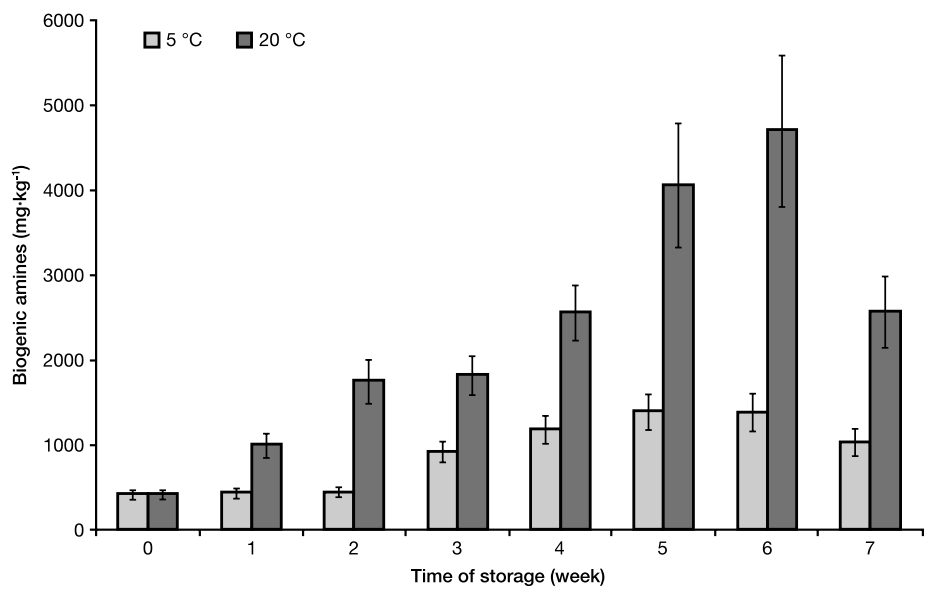

Fig.1. Influence of temperature and the period of storage on the total contents of the biogenic amines in cheese 
increased from week 3 to week $5(P<0.01)$ when stable concentrations were reached. At $20^{\circ} \mathrm{C}$, there were significantly higher levels $(P<0.01)$ than at $5^{\circ} \mathrm{C}$, and formation of BAs significantly increased from the start of storage. The BA content increased $(P<0.01)$ until week 6 when there was a drop in the content. A similar drop in BA production at the end of storage was detected in the Azeitão cheese (Pinho et al. 2001). Results in the present experiment showed that the BA content in cheeses is linked to the storage temperature. At lower temperatures the rate of BA production slows down and can also be suppressed at the start of storage at $5{ }^{\circ} \mathrm{C}$.

At $20^{\circ} \mathrm{C}$, very high contents of BAs were reached in the Olomouc curd cheese. Total BA content ranged in thousands of $\mathrm{mg} \cdot \mathrm{kg}^{-1}$ of the product and reached the levels of $>4 \mathrm{~g} \cdot \mathrm{kg}^{-1}$ of cheese. Concentrations of total BAs at $5{ }^{\circ} \mathrm{C}$ were approximately one-third of the concentrations when cheeses were stored at $20{ }^{\circ} \mathrm{C}$. Also, when cheeses were stored at $20^{\circ} \mathrm{C}$, all the individual BA concentrations were significantly higher $(P<0.01)$ when compared to the concentrations at storage temperature of $5^{\circ} \mathrm{C}$ (Table 3 ).

Table 3. Biogenic amine contents ${ }^{\text {a }}\left(\mathrm{mg} \cdot \mathrm{kg}^{-1}\right)$ in Olomouc curd cheese on the third week of storage and $\mathrm{T}$ values

\begin{tabular}{|c|c|r|c|}
\hline \multirow{2}{*}{ Amine $^{\mathrm{b}}$} & \multicolumn{2}{|c|}{ Temperature of storage } & $\mathrm{T}$ \\
\cline { 2 - 4 } & $5^{\circ} \mathrm{C}$ & $20^{\circ} \mathrm{C}$ & \\
\hline TRM & 8.2 & 42.6 & $7.763^{* *}$ \\
\hline PUT & 212.9 & 426.9 & $5.746^{* *}$ \\
\hline CAD & 300.9 & 470.5 & $4.579^{* *}$ \\
\hline HIM & 165.7 & 321.1 & $11.985^{* *}$ \\
\hline TYM & 224.9 & 524.2 & $8.805^{* *}$ \\
\hline SPD & 3.1 & 5.5 & $3.840^{* *}$ \\
\hline SPM & 5.1 & 16.2 & $29.069^{* *}$ \\
\hline
\end{tabular}

${ }^{\text {a }}$ mean values

${ }^{\mathrm{b}} \mathrm{TRM}=$ tryptamine, $\mathrm{PUT}=$ putrescine, $\mathrm{CAD}=$ cadaverine, $\mathrm{HIM}=$ histamine, $\mathrm{TYM}=$ tyramine, $\mathrm{SPD}=$ spermidine, $\mathrm{SPM}=$ spermine ${ }^{* *} P<0.01$

Critical $\mathrm{T}$ value for five repetitions, $\mathrm{T}$ (crit) $=3.106$
The BA profile also differed depending on storage conditions. Unlike the storage of cheeses at $5{ }^{\circ} \mathrm{C}$, when the histamine and tyramine contents were compared, tyramine levels were found to be two to three times higher than histamine in cheeses stored at $20{ }^{\circ} \mathrm{C}$. Similarly, when comparing the concentrations of cadaverine and putrescine, the difference in the levels was two times higher during the storage at $20^{\circ} \mathrm{C}$.

Assessing the impact of storage on BA production is complicated by the fact that cakes of Olomouc curd cheese are shipped by the producer at about one-third of its maturity, so the ripening takes place during the storage. As the content of BAs usually increases throughout the ripening period (Schneller et al. 1997), in the present experiment the values of BAs increased progressively throughout ripening, and the matured Olomouc curd cheese samples reached the toxicologically important contents of histamine and tyramine approximately in week 4 of storage.

\section{Chemical properties}

Results of the BA content during storage are also supported by the results of chemical analyses (Table 4). With storage time, the $\mathrm{pH}$ value increased and titratable acidity (in $\mathrm{SH})$ dropped significantly $(P<0.01)$. The $\mathrm{pH}$ increase was significant at a higher temperature $(P<0.01)$, whereas the $\mathrm{SH}$ decrease was at the same temperature significantly lower $(P<0.01)$. High $a_{\mathrm{w}}(\geq 0.95)$ indicates that suitable conditions for the growth of microorganisms are created, which is supported by a high $\mathrm{pH}$. On the other hand, it is limited by an increasing concentration of $\mathrm{NaCl}$. However, a change in other chemical properties was not detected.

\section{Sensory analyses}

Chemical analyses were carried out in parallel with determination of sensory assessment. Sensory scores during storage of samples at $5{ }^{\circ} \mathrm{C}$ and $20^{\circ} \mathrm{C}$ are shown in Table 5 . With respect to former experiments with the Azeitão cheese (Pinho et al. 2001), it was not 
Table 4. Influence of storage of Olomouc curd cheese on the chemical indicators of the cheese at $5{ }^{\circ} \mathrm{C}$ and $20^{\circ} \mathrm{C}$ a

\begin{tabular}{|c|c|c|c|c|c|c|c|c|c|c|c|c|}
\hline \multirow{2}{*}{$\begin{array}{c}\text { Time of } \\
\text { storage } \\
(\text { week })\end{array}$} & \multicolumn{9}{|c|}{ Chemical indicators } \\
\cline { 2 - 14 } & Dry matter $(\%)$ & \multicolumn{2}{|c|}{$\mathrm{pH}$} & \multicolumn{2}{|c|}{$\mathrm{SH}^{\mathrm{b}}$} & \multicolumn{2}{|c|}{ Fat $(\%)$} & \multicolumn{2}{c|}{$\mathrm{NaCl}(\%)$} & \multicolumn{2}{c|}{$\mathrm{a}^{\mathrm{b}}$} \\
\hline & $5^{\circ} \mathrm{C}$ & $20^{\circ} \mathrm{C}$ & $5^{\circ} \mathrm{C}$ & $20^{\circ} \mathrm{C}$ & $5^{\circ} \mathrm{C}$ & $20^{\circ} \mathrm{C}$ & $5^{\circ} \mathrm{C}$ & $20^{\circ} \mathrm{C}$ & $5{ }^{\circ} \mathrm{C}$ & $20^{\circ} \mathrm{C}$ & $5^{\circ} \mathrm{C}$ & $20^{\circ} \mathrm{C}$ \\
\hline 0 & 35.4 & $35.4^{\mathrm{NS}}$ & 5.8 & $5.9^{\mathrm{NS}}$ & 55.2 & $55.2^{\mathrm{NS}}$ & 0.1 & $0.1^{\mathrm{NS}}$ & 4.3 & $4.3^{\mathrm{NS}}$ & 0.957 & $0.957^{\mathrm{NS}}$ \\
\hline 1 & 35.2 & $35.7^{\mathrm{NS}}$ & 6.1 & $6.3^{*}$ & 56.1 & $49.5^{*}$ & 0.1 & $0.1^{\mathrm{NS}}$ & 4.3 & $4.5^{*}$ & 0.962 & $0.969^{\mathrm{NS}}$ \\
\hline 2 & 34.9 & $35.9^{\mathrm{NS}}$ & 6.3 & $6.8^{* *}$ & 32.6 & $37.2^{* *}$ & 0.1 & $0.1^{\mathrm{NS}}$ & 4.2 & $4.7^{* *}$ & 0.961 & $0.954^{\mathrm{NS}}$ \\
\hline 3 & 35.9 & $35.0^{\mathrm{NS}}$ & 6.2 & $6.9^{* *}$ & 29.8 & $35.7^{* *}$ & 0.1 & $0.1^{\mathrm{NS}}$ & 4.4 & $4.6^{\mathrm{NS}}$ & 0.964 & $0.953^{*}$ \\
\hline 4 & 35.2 & $35.8^{\mathrm{NS}}$ & 6.3 & $6.7^{* *}$ & 28.7 & $36.9^{* *}$ & 0.1 & $0.1^{\mathrm{NS}}$ & 4.4 & $5.0^{* *}$ & 0.966 & $0.950^{*}$ \\
\hline 5 & 35.1 & $35.1^{\mathrm{NS}}$ & 6.5 & $6.8^{* *}$ & 28.2 & $34.4^{* *}$ & 0.1 & $0.1^{\mathrm{NS}}$ & 4.4 & $5.1^{* *}$ & 0.986 & $0.965^{* *}$ \\
\hline 6 & 35.4 & $34.3^{*}$ & 6.9 & $7.1^{*}$ & 23.1 & $40.8^{* * *}$ & 0.1 & $0.1^{\mathrm{NS}}$ & 4.7 & $5.2^{* *}$ & 0.977 & $0.956^{* *}$ \\
\hline 7 & 35.1 & $35.1^{\mathrm{NS}}$ & 6.9 & $7.1^{*}$ & 28.9 & $39.1^{* * *}$ & 0.1 & $0.1^{\mathrm{NS}}$ & 4.8 & $5.5^{* *}$ & 0.969 & $0.953^{*}$ \\
\hline
\end{tabular}

${ }^{\text {a }}$ The values are the mean of 5 samples measured twice

${ }^{\mathrm{b}} \mathrm{SH}=$ titratable acidity, $\mathrm{a}_{\mathrm{w}}=$ water activity

${ }^{\mathrm{c}} \mathrm{NS}$ - not significant $P>0.05 ;{ }^{*} P<0.05 ;{ }^{* *} P<0.01 ;{ }^{* * *} P<0.001$

Table 5. Sensory analysis of Olomouc curd cheese stored at various temperatures $\left(5^{\circ} \mathrm{C}\right.$ and $\left.20{ }^{\circ} \mathrm{C}\right)$

\begin{tabular}{|c|c|c|c|c|c|c|c|c|c|c|c|c|}
\hline \multirow{3}{*}{ Characteristic $^{\mathrm{a}}$} & \multicolumn{12}{|c|}{ Time of storage (week) } \\
\hline & \multicolumn{2}{|c|}{0} & \multicolumn{2}{|c|}{1} & \multicolumn{2}{|c|}{2} & \multicolumn{2}{|c|}{3} & \multicolumn{2}{|c|}{4} & \multicolumn{2}{|c|}{5} \\
\hline & $5{ }^{\circ} \mathrm{C}$ & $20^{\circ} \mathrm{C}$ & $5^{\circ} \mathrm{C}$ & $20^{\circ} \mathrm{C}$ & $5^{\circ} \mathrm{C}$ & $20^{\circ} \mathrm{C}$ & $5^{\circ} \mathrm{C}$ & $20^{\circ} \mathrm{C}$ & $5^{\circ} \mathrm{C}$ & $20^{\circ} \mathrm{C}$ & $5^{\circ} \mathrm{C}$ & $20^{\circ} \mathrm{C}$ \\
\hline Colour & 3.5 & 3.5 & 4.0 & 6.0 & 8.5 & 8.0 & 8.5 & 3.0 & 7.0 & - & 2.5 & - \\
\hline Texture & 6.5 & 6.5 & 8.0 & 8.0 & 9.9 & 5.0 & 8.0 & 2.5 & 6.0 & - & 4.0 & - \\
\hline Odour & 6.0 & 6.0 & 7.0 & 7.5 & 8.5 & 7.0 & 8.5 & 2.0 & 7.0 & - & 3.0 & - \\
\hline Flavour & 3.5 & 3.5 & 5.0 & 6.0 & 7.0 & 6.5 & 8.5 & 2.0 & 8.5 & - & 2.5 & - \\
\hline Total $(100)^{\mathrm{b}}$ & 53.3 & 53.3 & 66.0 & 72.5 & 86.9 & 61.8 & 83.4 & 23.0 & 69.8 & - & 32.2 & - \\
\hline
\end{tabular}

a Characteristics: 1 (the worst), 10 (the best)

${ }^{\mathrm{b}}$ Total sensory score (100) - value in bracket is maximum attainable score

striking that samples stored at lower temperature showed better storage capability. Influence of temperature on the sensory score was substantial, length of storage was secondary. With regard to the durability time (35 days) sensory assessment was conducted over the storage period of up to 5 weeks. The assessment of samples stored at $20^{\circ} \mathrm{C}$ was stopped after 3 weeks, because it was difficult to perform the sensory evaluation due to decomposition of the cheese. Samples stored at $5{ }^{\circ} \mathrm{C}$ were evaluated for 5 weeks.

As the cheese is supplied by the producer in about one-third of its maturity, the first part of storage time is associated with ripening; it lasts approximately three weeks. The valuation of sensory properties of cheese stored at $5{ }^{\circ} \mathrm{C}$ shows that the cheese has the best sensory score from the third to fourth week of storage, when its odour and flavour has fully expanded. Storage over four to five weeks was connected with changes of texture (spilling) and pungent flavour. An increase of negative sensory properties was found at $20^{\circ} \mathrm{C}$; after 3 weeks the samples were spoiled.

A correlation matrix was calculated for the amine content and the sensory score. At both temperatures, no significant Spearman correlations between the amine contents and the sensory score were observed. At $5^{\circ} \mathrm{C}$, negative sensory effects were observed sooner than the BA contents reached high values. At $20^{\circ} \mathrm{C}$ the formation of high levels of BAs preceded the sensory signals. Similar results were presented by Komprda (2005). It may be that the formation of BAs at $5{ }^{\circ} \mathrm{C}$ is connected with ripening in the first stage of storage, while at $20^{\circ} \mathrm{C}$ another decomposition process plays an important role.

As the kinetic curves of BA formation show an increase, they can be described by quadratic or cubic equations (Krŕížek et al. 2004). By solving these equations for proposed critical 
toxicological concentration of $900 \mathrm{mg} \cdot \mathrm{kg}^{-1}$ we obtained values of the storage interval limit, when the given concentration had been reached (Table 6).

Table 6. Days of storage of Olomouc curd cheese when given histamine + tyramine + putrescine + cadaverine contents can be awaited

\begin{tabular}{|c|c|c|c|}
\hline \multicolumn{4}{|c|}{ Calculated critical days of storage } \\
\hline $\begin{array}{c}\text { Temperature } \\
\left({ }^{\circ} \mathrm{C}\right)\end{array}$ & $\begin{array}{c}\text { HIM }+ \text { TYM + PUT }+\mathrm{CAD}^{\mathrm{a}} \\
900 \mathrm{mg} \cdot \mathrm{kg}^{-1}\end{array}$ & $r_{s}^{\mathrm{b}}$ & Sens. $^{\mathrm{c}}$ \\
\hline 5 & 24.1 & $0.884^{* * *}$ & $81.8^{\mathrm{d}}$ \\
\hline 20 & 7.9 & $0.959^{* * *}$ & $72.5^{\mathrm{d}}$ \\
\hline
\end{tabular}

${ }^{\mathrm{a}} \mathrm{HIM}=$ histamine, $\mathrm{TYM}=$ tyramine, $\mathrm{PUT}=$ putrescine, $\mathrm{CAD}=$ cadaverine

${ }^{\mathrm{b}} r$ - Spearman's correlation coefficient

${ }^{* * *} P<0.001$

${ }^{\mathrm{c}}$ Sens. - Total sensory score determined at calculated time

d Total score - value 100 is maximum attainable score
Table 6 shows that the temperature was critical for toxicological quality of samples during storage. The critical concentration of histamine + tyramine + putrescine + cadaverine in samples stored at $5{ }^{\circ} \mathrm{C}$ was reached $16-17$ days later than in those stored at $20^{\circ} \mathrm{C}$. The data of critical concentration correspond to those of hygienically important contents of histamine and tyramine.

In conclusion, the results obtained in this study showed that the important factors in BA production in the Olomouc curd cheese were the storage period and storage temperature.
With storage over a period of 7 weeks at a temperature of $20^{\circ} \mathrm{C}$, the concentration of total amines was more than threefold compared to the concentrations found at $5{ }^{\circ} \mathrm{C}$, and reached $4600 \mathrm{mg} \cdot \mathrm{kg}^{-1}$ in week 6 of storage. The most quantitatively important BAs were cadaverine and tryptamine. BA production was also associated with the process of ripening. The study results also show that cadaverine and tyramine can serve as indicators of temperature changes in cheese during distribution and retail selling.

Sensory assessment was carried out in parallel with chemical determination. The best sensoric properties of cheese at $5^{\circ} \mathrm{C}$ were approximately in the forth week of storage which corresponded to the time when established toxicological limit for histamine + tyramine + putrescine + cadaverine $=900 \mathrm{mg} \cdot \mathrm{kg}^{-1}$ of the consumed food was exceeded. With respect to high variability of BA profile and potential high BA content, Olomouc curd cheese is thus considered a potentially hazardous product. Individuals suffering from food intolerance and food allergies, and patiens receiving monoamine oxidase inhibitors should avoid consumption of such cheese.

From this perspective, it is important to establish the expiration dates for cheese consumption. In case Olomouc cake of cheese, the data can be specified as fourth week of storage at $5{ }^{\circ} \mathrm{C}$. This conclusion applies under the condition of good hygiene and production practice and targets a consumer outside the risk-group consumers.

Further work is underway in order to determine other factors influencing biogenic amines and polyamines in the Olomouc curd cheese, in particular the presence of microorganisms with decarboxylase activity.

\section{Tvorba biogenních aminů v olomouckých tvarůžcích za různých podmínek skladování}

Cílem předkládané práce bylo posoudit vliv teploty a doby skladování na tvorbu biogenních aminů (BA) u tradičních českých sýrů - tvarůžků. Vzorky byly skladovány po dobu 7 týdnů při teplotách $5^{\circ} \mathrm{C}$ a $20^{\circ} \mathrm{C}$. BA byly stanoveny jako dansylderiváty metodou RP-HPLC s fluorescenční detekcí, histamin byl detekován pomocí detektoru s diodovým polem. Současně byly u sýrů stanoveny fyzikální a chemické vlastnosti metodami dle ČSN a provedeno sensorické zhodnocení deskriptorů (vzhledu, barvy, vůně, textury a chuti). Jako hlavní aminy byly stanoveny kadaverin (124-2 $413 \mathrm{mg} \cdot \mathrm{kg}^{-1}$ ) a tyramin (117-1 $\left.058 \mathrm{mg} \cdot \mathrm{kg}^{-1}\right)$, nižší koncentrace byly nalezeny u putrescinu $\left(75-767 \mathrm{mg} \cdot \mathrm{kg}^{-1}\right)$ 
a histaminu (74-411 $\left.\mathrm{mg} \cdot \mathrm{kg}^{-1}\right)$. Obsahy tryptaminu, sperminu a spermidinu byly nízké. Při skladování koncentrace celkových BA významně rostly po celou dobu skladování $(P<0,01)$ a významně závisely na teplotě $(P<0,01)$. Obsah celkových BA při teplotě $20^{\circ} \mathrm{C}$ byl více než trojnásobný ve srovnání s hodnotami nalezenými u sýra při teplotě $5{ }^{\circ} \mathrm{C}$ a na konci skladování dosáhl hodnoty $4600 \mathrm{mg} \cdot \mathrm{kg}^{-1}$. Z hlediska toxikologického kritická hodnota pro sýr $900 \mathrm{mg} \cdot \mathrm{kg}^{-1}$ jako suma histaminu + tyraminu + putrescinu + kadaverinu byla při $5{ }^{\circ} \mathrm{C}$ dosažena o 17 dní skladování později něž při $20{ }^{\circ} \mathrm{C}$. Vzorky sýrů skladovaných při $5{ }^{\circ} \mathrm{C}$ sensoricky vyhovovaly po celou dobu minimální trvanlivosti. Znalost vlivů různých podmínek skladování na tvorbu biogenních aminů v sýrech je důležitá, aby bylo možné snížit riziko spojené s konzumací sýrů, které obsahují vysoké koncentrace BA.

\section{Acknowledgments}

The project received support from the research project of the Ministry of Education, Youth, and Sport entitled "Veterinary Aspects of Food Safety and Quality" MSM 6215712402.

\section{References}

Bardócz S, Grant G, Brown DS, Ralph A, Pusztai A 1993: Polyamines in food implications for growth and health. J Nutr Biochem 4: 66 - 71

Council Regulation (EC) No. 510/2006 “Olomoucké tvarůžky” EC No: CZ/PGI/005/0399/ 19. 10. 2004, OJ C $182 / 20-22,4.8 .2007$

ČSN 570107 1980: Metody zkoušení př́rodních a tavených sýrů. Stanovení kyselosti. (Testing methods for natural and processed cheese. Determination of acidity), Český normalizační institut, Praha, p. 17-18

ČSN 570107 1980: Metody zkoušení prŕrodních a tavených sýrů. Stanovení pH potenciometricky - rozhodčí metoda. (Testing methods for natural and processed cheese. Determination of $\mathrm{pH}$ by potenciometry (Reference method)), Český normalizační institut, Praha, p. 18

ČSN ISO 5943 1996: Sýry a tavené sýrové výrobky - Stanovení obsahu chloridů. Potenciometrická titrační metoda. (Cheese and processed cheese products. - Determination of chloride content. - Potentiometric titration method), Český normalizační institut, Praha, 8 p.

ČSN ISO 5534 2005: Sýry a tavené sýry - Stanovení obsahu celkové sušiny (Referenční metoda). (Cheese and processed cheese - Determination of total solids content (Reference method)), Český normalizační institut, Praha, 12 p.

ČSN EN ISO 1735 2005: Sýry a tavené sýrové výrobky - Stanovení obsahu tuku - Gravimetrická metoda (Referenční metoda). (Cheese and processed cheese products - Determination of fat content. - Gravimetric method (Reference method)), Český normalizační institut, Praha, 20 p.

Dičáková Z, Dudriková E 2007: Is it correlation between putrefaction factors and putrescine presence in cheese? Pages 138-148 in Proc. Hygiena Alimentorum XXVIII "Safety and Quality of Milk and Milk Products" Strbské Pleso - Vysoké Tatry, Slovakia, May 2-4

Fernández-García E, Tomillo J, Nunez M 2000: Formation of biogenic amines Hispánico cheese manufactured with proteinases and different levels of starter culture. J Food Prot 63:1551-1555

Forman L 1996: Mlékárenská technologie, $2^{\text {nd }}$ Ed., Institute of Chemical Technogy, Prague, 228 p.

Giraffa G, Pepe G, Locci F, Neviani E, Carminati D 1995: Hemolytic activity, production of thermonuclease and biogenic amines by dairy enterococci. Italian J Food Sci 4: 341-349

Greif G, Greifová M, Drdák M 1997: Stanovenie biogénnych aminov v potravinách živočišného pôvodu metódou HPLC. Potrav Vědy 15:119-129

HalászA, Baráth A, Simon-Sarkadi L, Holzapfel W 1994: Biogenic amines and their production by microorganisms. Trends Food Sci Technol 5: 42-49

Joosten HMLJ 1988: Conditions allowing the formation of biogenic amines in cheese. 3. Factors influencing the amount formed. Neth Milk Dairy J 42: 329-357

Kalač P, Krausová P 2005: A review of dietary polyamines: Formation, implications for growth and health and occurrence in foods. Food Chem 90: 219-230

Komprda T 2005: Biogenic amines and polyamines in the fermented foodstuffs of animal origin. Veterinářství 55: 646-650

Komprda T, Smělá D, Novická K, Kalhotka L, Šustová K, Pechová P 2007: Content and distribution of biogenic amines in Dutch-type hard cheese. Food Chem 102: 129-137

Kondyli E, Katsiairi MC, Voutsinas LP 2008: Chemical and sensory characteristics of Galotyri-type cheese made using different procedures. Food Control 19: 301 - 307

Kř́žzek M, Kalač P 1998: Biogenic amines in foods and their roles in human nutrition. Czech J Food Sci 16: 151-159

Křrižek M, Vácha F, Vorlová L, Lukášová J, Cupáková Š 2004: Biogenic amines in vacuum-packed and nonvacuum-packed flesh of carp (Cyprinus carpio) stored at different temperatures. Food Chem 88: 185-191 
Novella-Rodríguez S, Veciana-Nogués MT, Vidal-Carou MC 2000: Biogenic amines and polyamines in milks and cheese by ion-pair high performance liguid chromatography. J Agric Food Chem 48: 5117-5123

Paulsen P, Bauer F, Vali S 1997a: Biogene Amine in Rohwuersten. 1. Methodische Aspekte zur Bestimmung biogener Amine. Fleischwirtschaft 77: 450-452

Paulsen JE, Reistad R, Eliassen KA, Sjaastad OV, Alexander J 1997b: Dietary polyamines promote the growth of azoxymethane-induced aberrant crypt foci in rat colon. Carcinogenesis 18: 1871-1875

Petridis KD, Steinhart H 1995: Automatische Vorsäulenderivatisierung mit o-Phtaldehyd (OPH). Z Lebensm Unters Forsch A 201: 256-260

Pinho O, Ferreira IMPLVO, Mendés E, Oliveira BM, Ferreira M 2001: Effect of temperature on evolution of free amino acid and biogenic amine contents during storage of Azeitão cheese. Food Chem 76: 287-291

Rak L 2005: Biogenne aminy v serach. Medycyna Wet 61: 391-393

Roig-Sagués AX, Molina AP, Hernándes-Herrero MM 2002: Histamine and tyramine-forming microorganismus in Spanish traditional cheeses. Eur Food Res Technol 215: 96-100

Silla-Santos MH 1996: Biogenic amines: their importance in foods. Int J Food Microbiol 29: 213-231

Simon-Sarkadi L, Hodosi E 1995: Determination of biogenic amine in food using amino acid analyzer. Proc Eur Food Chem VIII 2: 486-489

Schneller R, Good P, Jenny M 1997: Influence of pasteurized milk, raw milk and different ripening cultures on biogenic amine concentrations in semi-soft cheeses during ripening. Z Lebensm Unters Forsch A 204: $265-272$

Spanier MC, Bruin TJF, Van Roode BASW 1991: HPLC determination of biogenic amines and evaluation of results. Food Policy Trends in Europe Nutrition technology, analysis and safety 6: 213 p.

Stratton JE, Hutkins RW, Taylor S 1991: Biogenic amines in cheese and other fermented foods: a review. J Food Prot 54: 460-470

Ten Brink B, Damink C, Joosten H, Hui In'T Velt J 1990: Occurence and formation of biologicalty active amines in foods. Int J Food Microbiol 11: 73-84

Valsamaki K, Michaelidou A, Polychroniadou A 2000: Biogenic amine production in Feta cheese. Food Chem 71: $259-266$ 